\title{
STUDY ON ACCOUNTING ORGANIZATION: OPTIONS AND INFLUENCE FACTORS
}

\author{
Alina-Teodora CIUHUREANU \\ "Nicolae Bălcescu" Land Forces Academy, Sibiu, Romania \\ alinaciuhureanu@yahoo.com
}

\begin{abstract}
In the current economic environment that characterizes the business environment in Romania, organizing and conducting accounting is a challenge. The option of effective accounting organization is a choice of management that needs to be carefully analyzed but which is also based on a number of factors of influence. Starting from these aspects, we propose to analyze the way in which accounting is organized within the economic entities, taking into account their category and field of activity. We also sought to identify the main factors that influenced the choice of a way of organizing accounting. The study was conducted on a sample of 301 economic entities in the Development Region 7 Center - Romania.
\end{abstract}

Keywords: accounting, organization, economic entity, internalization, outsourcing

\section{Introduction}

According to the provisions of the Accounting Law 82/1991 [1], republished, in the case of economic entities, the administrator is responsible for organizing the accounting. It is a particularly important decision if we take into account that any economic entity generates, through the accounting information system, financial information used in making decisions by internal and external users. Thus, we believe that accounting information, records and mandatory reporting [3] must be reliable [2] for managers / administrators and external users alike.

Is there a connection between the way in which the accounting activity is organized and the internal use of the accounting information? The answer to this question tends to be directed to the "no" option. Following discussions with various professionals, both in the accountancy and management profession and on the basis of my personal professional experience, I have noticed that in most cases the use of accounting information is an option of the management of economic entities which, unfortunately, often it is more interested in taxation, in the possibilities to "juggle" for the postponement of tax obligations and does not concern the entity that generates value, especially in case of listed companies [5], in terms of minimizing risks by knowing and understanding what is behind the supporting documents or declaratory obligations. Although the situation is abnormal for a healthy business environment, we can not but agree with those in charge of managing the entity and assimilate accounting with taxes, fees, contributions, and taxation. However, this is the current economic context, dominated by major changes in the area of taxation, made overnight, which raises doubts in the practical activity, inconsistencies or sometimes the impossibility to carry out the accounting activity. 


\section{Accounting options}

The accounting activity is carried out through a series of responsibilities attributable to Law 82/1991 and can be stated as follows: the chronological and systematic registration of the record documents; the synthetic and analytical bookkeeping of the components of assets and liabilities; cashing and payment operations; valuation of assets, debts and equity; recording differences in inventory; keeping up-to-date the mandatory registers; calculating the and accounting (and tax) results monthly, quarterly and annually; elaboration of periodic and annual reports; cost calculation, etc. Considering the legislative provisions and the economic practice, in our opinion, from the perspective of the organizational function, the accounting can be made internalized, externalized or mixed.

Regarding the internalized version, we consider that this is especially appropriate for economic entities whose volume of activity is relatively high and for which supporting documents, situations, summaries etc. are needed daily. One of the essential aspects to be taken into consideration in the internalized version is the fact that the responsible person / person authorized to lead a separate accounting department must have, according to Law 82/1991, republished, higher educationin economic studies.

Another option of accounting organization

is outsourcing on the basis of service contracts concluded with authorized persons or companies, members of the Body of Chartered Accountants and Authorized Accountants of Romania. In our opinion, the option of outsourcing is recommended for companies whose volume of activity and / or object of activity allows complete outsourcing or the implementation of an on-line accounting system. The latter option, and perhaps the one that is often used, is the option of a mixed organization, namely the existence of one or more persons employed in the accounting department at the same time as the conclusion of a contract for specialized services.

Choosing the organizational way takes into account the complexity of the activities that are subordinated to it, the size of the entity, costs, etc. and can have effects in capitalizing accounting information for internal and external users.

\section{Methodology of selective research}

The study is part of the sample of quantitative selective surveys. For its application, the questionnaire was used as a tool, with a total number of 78 items. The sample consisted of 301 active economic entities in the Central Region - Romania. The methodological steps of the research were followed according to those presented by the specialist Iacob Cătoiu [4]. The research objectives and hypotheses are presented in table no. 1 .

Table 1 Objectives and hypotheses of research

\begin{tabular}{|c|c|c|c|}
\hline Central objective & Main hypotheses & $\begin{array}{l}\text { Secondary } \\
\text { objectives }\end{array}$ & Secondary hypotheses \\
\hline $\begin{array}{l}\boldsymbol{Q}_{1} \text { Identifying the } \\
\text { option to organize } \\
\text { accounting }\end{array}$ & $\begin{array}{l}\boldsymbol{I P}_{2}-\text { The accounting } \\
\text { organization option is } \\
\text { directly related to the } \\
\text { entity's category and } \\
\text { is most often } \\
\text { influenced by the cost } \\
\text { reduction. }\end{array}$ & $\begin{array}{l}\boldsymbol{Q}_{1.1} \text { Identifying the } \\
\text { extent to which the } \\
\text { organization of } \\
\text { accounting is } \\
\text { influenced by the } \\
\text { category and the } \\
\text { field of activity. }\end{array}$ & $\begin{array}{l}\boldsymbol{I S}_{\boldsymbol{I}^{-}} \text {The bigger the size of the } \\
\text { entity and the more complex the } \\
\text { activity, the more managers are } \\
\text { oriented towards the } \\
\text { internalization of the accounting } \\
\text { or its organization in a mixed } \\
\text { version. }\end{array}$ \\
\hline \multicolumn{4}{|c|}{$\begin{array}{ll}\text { 3. Results of the study } & \text { formulated in the questionnaire, the } \\
\text { In order to know the way in which the processing of the obtained answers being } \\
\text { accounting is organized in the economic }\end{array}$} \\
\hline
\end{tabular}


Table2.Organization of accounting

\begin{tabular}{|l|l|r|r|r|}
\hline Valid & \multicolumn{1}{|c|}{ Option } & Frequency & Percentage & \multicolumn{1}{c|}{$\begin{array}{c}\text { Valid } \\
\text { percentage }\end{array}$} \\
\hline 301 & Internalized & 103 & 34,22 & 34,22 \\
\hline & Externalized / outsourced & 88 & 29,24 & 29,24 \\
\hline & Mixed & 110 & 36,54 & 36,54 \\
\hline Total & & 301 & 100,00 & 100,00 \\
\hline
\end{tabular}

Regarding the organization of the accounting, we can notice that the distribution is relatively similar for the three possibilities. Thus, the mixed share $(36.54 \%)$ has the highest share, for internalization $34.22 \%$ of the investigated economic entities opted and outsourcing was chosen by $29.24 \%$ of them. We considered that a simple statistic in this sense is not enough, not having the possibility to draw really useful conclusions

that capture the profile of the economic entities, which is why we have used associations in the secondary objective $\mathrm{Q}_{1.1}$ - Identifying the extent to which the organization of accounting is influenced by the category and the field of activity. A first association aimed to analyze how the organization was organized according to the category of the entity $\left(\mathrm{v}_{10}\right.$ with $\left.\mathrm{v}_{2}\right)$, the answers obtained being presented in table 3 .

Table 3.Organization of accounting according to the category of the economic entity

\begin{tabular}{|c|c|c|c|c|c|}
\hline \multirow{2}{*}{$\begin{array}{l}\text { Organization } \\
\text { of accounting }\end{array}$} & \multicolumn{4}{|c|}{ Category of the economic entity } & \multirow{2}{*}{$\begin{array}{c}\text { Total } \\
\%\end{array}$} \\
\hline & micro & small & middle-sized & big & \\
\hline \multirow{2}{*}{$\begin{array}{c}\text { internalized } \\
\%\end{array}$} & 22 & 19 & 46 & 16 & 103 \\
\hline & 14,86 & 22,62 & 88,46 & 94,12 & 34,22 \\
\hline \multirow{2}{*}{$\begin{array}{c}\text { externalized / } \\
\text { outsourced } \\
\% \\
\%\end{array}$} & 52 & 36 & 0 & 0 & 88 \\
\hline & 35,14 & 42,86 & 0,00 & 0,00 & 29,24 \\
\hline \multirow{2}{*}{$\begin{array}{c}\operatorname{mixt} \\
\%\end{array}$} & 74 & 29 & 6 & 1 & 110 \\
\hline & 50,00 & 34,52 & 11,54 & 5,88 & 36,54 \\
\hline \multirow{2}{*}{$\begin{array}{r}\text { Total } \\
\%\end{array}$} & 148 & 84 & 52 & 17 & 301 \\
\hline & 100,00 & 100,00 & 100,00 & 100,00 & 100,00 \\
\hline
\end{tabular}

The analysis of the way of organizing accounting correlated with the category of entities shows that the majority of microentities opt for the mixed option $(50 \%)$ and outsourcing $(35.14 \%)$, at the opposite pole being the middle-sized and big ones, which, in a proportion ofover $88 \%$ internalize this activity. Also, for the two categories it is pointed out that the outsourcing option is not chosen. With regard to medium-sized entities, the options are distributed for all three organizational modalities, noting that internalization is the least used $(22.62 \%)$.

The field of activity may be another variable in choosing how to organize the accounting. To highlight this aspect, we associated $\mathrm{v}_{10}$ with $\mathrm{v}_{2}$, aiming to know how to organize based on the field of activity, the answers being presented in table 4 . 
Table 4.Organization of accounting according to the field of activity

\begin{tabular}{|c|c|c|c|c|c|}
\hline \multirow{2}{*}{$\begin{array}{l}\text { Organization of } \\
\text { accounting }\end{array}$} & \multicolumn{4}{|c|}{ Field of activity } & \multirow{2}{*}{$\begin{array}{c}\text { Total } \\
\%\end{array}$} \\
\hline & Commerce & Industry & Services & Agriculture & \\
\hline \multirow{2}{*}{$\begin{array}{c}\text { internalized } \\
\%\end{array}$} & 26 & 50 & 24 & 3 & 103 \\
\hline & 42,62 & 66,67 & 15,48 & 30,00 & 34,22 \\
\hline \multirow{2}{*}{$\begin{array}{c}\text { externalized / } \\
\text { outsourced } \\
\%\end{array}$} & 18 & 6 & 59 & 5 & 88 \\
\hline & 29,51 & 8,00 & 38,06 & 50,00 & 29,24 \\
\hline \multirow{2}{*}{$\begin{array}{c}\operatorname{mixt} \\
\%\end{array}$} & 17 & 19 & 72 & 2 & 110 \\
\hline & 27,87 & 25,33 & 46,45 & 20,00 & 36,54 \\
\hline \multirow{2}{*}{$\begin{array}{r}\text { Total } \\
\%\end{array}$} & 61 & 75 & 155 & 10 & 301 \\
\hline & 100,00 & 100,00 & 100,00 & 100,00 & 100,00 \\
\hline
\end{tabular}

Analyzing the information above, we note that the most obvious is internalization in industry, with $66.67 \%$ of the surveyed entities opting for this variant. This result was predictable if we consider that $64.71 \%$ of the entities operating in this area are in the category of big companies (see table 3 ). We also have to note the very low share $(8 \%)$ of those who opt for outsourcing, which we consider emphasizing a link between the complexity of activities and the way of organizing the accounting (the field of industry generally involves activities that are more complex and lead to the necessity of having accounting staff within the entity). As far as agriculture is concerned, $50 \%$ of entities opt for outsourcing, most of which fall into the category of micro and small entities. Service categoryis best represented by the mixed option, anoption preferred by $46.45 \%$ of entities.

In conclusion, the personal opinion presented in the paper is confirmed: the bigger the size of the entity and the more complex the activity, the managers / administrators are more oriented towards the internalization of the accounting or its organization in mixed variant, which leads to the validation of the secondary hypothesis $\mathrm{IS}_{1}$.

Given the assumption that the size of an entity is no longer a direct factor in organizing accounting, we ask ourselves what the main reasons in taking the decisionare. Does the cost, the skills, the informational technologies etc. matter? The decision belongs to each manager or administrator and is often adopted solely on the basis of costs. How many times did we not hear the phrase "It's too much!!, I only have 10 bills", without asking what reports are being offered, what the informational benefits to leadershipare. Based on these considerations, through the operational variable $\mathrm{v}_{11}$, we aimed to determine the importance of the criteria underlying the choice of the way of organizing the accounting, the information being presented in table 5.

Table 5.Criteria for choosing how to organize accountancy

\begin{tabular}{|l|c|c|c|c|c|c|}
\hline Criteria & $\begin{array}{c}\text { not at all } \\
\text { important }\end{array}$ & $\begin{array}{c}\text { little } \\
\text { important }\end{array}$ & neutral & important & $\begin{array}{c}\text { very } \\
\text { important }\end{array}$ & Total \\
\hline \multicolumn{7}{|c|}{ A. Cost reduction Score $=3,75$} \\
\hline Frequency & 24 & 46 & 33 & 76 & 122 & 301 \\
\hline Percentage \% & 7,97 & 15,28 & 10,96 & 25,25 & 40,53 & 100,00 \\
\hline \multicolumn{7}{|c|}{ B. Cost / quality / benefits ratio Score $=4,40$} \\
\hline Frequency & 0 & 15 & 28 & 81 & 177 & 301 \\
\hline Percentage \% & 0,00 & 4,98 & 9,30 & 26,91 & 58,80 & 100,00 \\
\hline \multicolumn{7}{|c|}{ C. Knowledge and skillsScore $=4,76$} \\
\hline Frequency & 0 & 0 & 11 & 49 & 241 & 301 \\
\hline
\end{tabular}




\begin{tabular}{|c|c|c|c|c|c|c|}
\hline Percentage \% & 0,00 & 0,00 & 3,65 & 16,28 & 80,07 & 100,00 \\
\hline \multicolumn{7}{|c|}{ D. Better communication Score $=3,95$} \\
\hline Frequency & 10 & 12 & 47 & 145 & 87 & 301 \\
\hline Percentage \% & 3,32 & 3,99 & 15,61 & 48,17 & 28,90 & 100,00 \\
\hline \multicolumn{7}{|c|}{ E. Access to information technology Score $=3,02$} \\
\hline Frequency & 43 & 62 & 86 & 67 & 43 & 301 \\
\hline Percentage \% & 14,29 & 20,60 & 28,57 & 22,26 & 14,29 & 100,00 \\
\hline \multicolumn{7}{|c|}{ F. Control Score $=2,62$} \\
\hline Frequency & 31 & 46 & 85 & 43 & 48 & 301 \\
\hline Percentage \% & 10,30 & 15,28 & 28,24 & 14,29 & 15,95 & 100,00 \\
\hline \multicolumn{7}{|c|}{ G. CreativityScore $=3,27$} \\
\hline Frequency & 19 & 82 & 63 & 72 & 65 & 301 \\
\hline Percentage \% & 6,31 & 27,24 & 20,93 & 23,92 & 21,59 & 100,00 \\
\hline \multicolumn{7}{|c|}{ H. Use of information Score $=3,71$} \\
\hline Frequency & 26 & 58 & 64 & 153 & 34 & 301 \\
\hline Percentage \% & 8,64 & 19,27 & 21,26 & 50,83 & 11,30 & 100,00 \\
\hline \multicolumn{7}{|c|}{ I. Trust Score $=4,75$} \\
\hline Frequency & 0 & 0 & 6 & 63 & 232 & 301 \\
\hline Percentage \% & 0,00 & 0,00 & 1,99 & 20,93 & 77,08 & 100,00 \\
\hline
\end{tabular}

Analyzing the obtained results, we note that despite the expectations, the main criterion that influences the way of organizing the accounting is represented by "knowledge and skills", which obtains a score of 4.76 and is thus ranked in the very important category. Applying the system of sincerity is a result I personally did not expect but I remembered the phrase "I'm looking for a good accountant".We highlight the term "good" because we have never got a clear answer to what good means. Fortunately, I am pleased to note that this term refers to the knowledge and skills of those involved in accounting. But let us not manifest this feeling too quickly because other operational variables have been introduced within the research tool that link these knowledge and skills to the options of capitalizing accounting information or to determine the interest of managers in the use of accounting information.

Returning to the information gathered, in the category of very important criteria, we identify trust that obtained a score of 4.75 , being considered very important in the decision making by $77.78 \%$ of the respondents. We believe that the respondents therefore stress the need for information not to be distributed, the professional accountant being regarded as "a doctor", and we appreciate the importance of trust, as is normal in a competitive economy in which only those who can survive. However, we will also come to the issues of creativity, where we can raise questions about trust.

In the category of important criteria we find the cost / quality / benefit ratio with a score of 4.40, better communication (3.95), cost reduction (3.75), use of information (3.71). In the "others" category, the respondents also mentioned relations with authorities, behavior, willingness to work, responding to requests.

The conclusions drawn from the processing of the data obtained through $\mathrm{v}_{10}$ and $\mathrm{v}_{11}$ lead to partial confirmation of the hypothesis launched before the survey $\left(\mathrm{IP}_{2}\right.$ The accounting option is directly related to the category of the entity and is most often influenced by the cost reduction), pointing out that there is anobviouslink between the decision to organize the accounting activity and the category of the entity, the main criterion being the knowledge and skills of the professional accountants, the partial results confirming the hypothesis launched before the research. 


\section{Final conclusions}

After processing the obtained data, we conclude that according to the organization of the accounting, the distribution is relatively similar for the three options: internalized, externalized and mixed, the organization being dependent on the category of economic entities and the field of activity. The primary criterion that influences how accounting is organized is the "knowledge and skills" of professional accountants, followed by trust and cost / quality / benefit ratio.

\section{References}

[1] Law on accounting no. 82/24.12.1991, republished, Official Gazette no. 292/15.04.2008, as amended and supplemented.

[2] Bill Whitmore, James A. Albers, Knowledge Management In An Accounting Organization, Journal of Knowledge Management Practice, Vol. 7, No. 4, December 2006, available on-line at http://www.tlainc.com/articl123.htm

[3] Order of the Ministry of Finance no. 1802/29.12.2014 for the approval of the Accounting Regulations on the individual annual financial statements and the consolidated annual financial statements, Official Gazette. no. 963 / 30.12.2014, as amended and supplemented.

[4] Cătoiu Iacob (coord.), Cercetări de marketing - tratat, Ed. Uranus, București, 2009 http://www.armyacademy.ro

[5] Diana Elena Vasiu, Balteş Nicolae, Gheorghe Iulian. Economic Value Added (EVA). A structural and dynamic analysis, during 2006-2013, of the companies having the business line in industry and construction, listed and traded on The Bucharest Stock Exchange, 2015, Revista „Theoretical and Applied Economics” Ediţie Supliment 2015, pp. 343-353 